\title{
REMEDIASI MISKONSEPSI SISWA DALAM MATERI CERMIN MENGGUNAKAN MEDIA ANIMASI DI KELAS VIII MTS AL ANWAR PONTIANAK
}

\author{
Endah Atitya ${ }^{1}$, Muhamad Firdaus ${ }^{2}$, Wahyudi ${ }^{3}$ \\ ${ }^{123}$ Program Studi Pendidikan Fisika, Fakultas PMIPATEK, IKIP PGRI Pontianak, Jl. \\ Ampera No. 88, Kota Pontianak \\ 1e-mail: Endahatitya09@yahoo.com
}

\begin{abstract}
Abstrak
Tujuan dalam penelitian ini adalah untuk menggali miskonsepsi siswa dan melakukan remediasi miskonsepsi siswa dalam materi cermin menggunakan media animasi pada siswa MTs Al Anwar Pontianak. Metode yang digunakan dalam penelitian ini adalah pre-ekperimental design dengan rancangan One Group Pre-test-Posttest. Teknik pengumpulan data yang digunakan adalah teknik pengukuran dengan instrumen berupa tes diagnostik tiga tingkat. Hasil Analisis data pada tes diagnostik menunjukkan bahwa seluruh siswa mengalami miskonsepsi pada materi cermin. Miskonsepsi sifat bayangan pada cermin datar merupakan miskonsepsi yang paling besar dialami siswa yaitu $64,71 \%$, selain itu siswa juga mengalami miskonsepsi sebesar $58,82 \%$ pada konsep aplikasi cermin datar. Setelah diberikan remediasi terjadi penurunan yang signifikan pada jumlah miskonsepsi siswa dalam materi cermin. Hasil perhitungan rata-rata penurunan pada jumlah miskonsepsi tiap siswa maupun tiap konsep menurut harga proporsi yaitu 0,59 dan 0,61 tergolong sedang, sehingga disimpulkan bahwa penggunaan media animasi cukup efektif untuk meremediasi miskonsepsi siswa dalam materi cermin.
\end{abstract}

Kata Kunci: Remediasi, Miskonsepsi, Animasi, Konsep Cermin.

\begin{abstract}
The purpose of this research was to explore student misconception and to remediate student misconception in mirror material using animation media at MTs Al Anwar Pontianak students. The method of this research was pre-experimental design with One Group Pre-test-Posttest design. A data collection technique was measurement techniques with instruments in the form of three-level diagnostic tests. The result of data analysis on diagnostic tests shows that all students have misconceptions on the mirror material. Misconception of the shadow properties in the data mirror is the biggest misconception experienced by students that is $64.71 \%$, besides the students also have misconception of $58.82 \%$ on the concept of flat mirror applications. After being given remediation there was a significant decrease in the number of student misconceptions in the mirror material. The average result of the decrease in the number of misconceptions each student or any concept according to the proportion of 0,59 and 0,61 is moderate. It can be concluded that the use of animation media is effective enough to remediate students' misconception in mirror material.
\end{abstract}

Keywords: Remediation, Misconception, Media Animation, Mirror. 


\section{PENDAHULUAN}

Fisika merupakan ilmu fundamental yang menjadi tulang punggung bagi perkembangan ilmu pengetahuan dan teknologi. Pentingnya pembelajaran fisika di SMP/MTS juga dijelaskan dalam Depdiknas (2006) yang mengatakan bahwa pembelajaran fisika bertujuan agar peserta didik memiliki kemampuan mengembangkan pemahaman tentang berbagai gejala alam konsep dan prinsip IPA yang bermanfaat dan dapat diterapkan dalam kehidupan sehari-hari. Tujuan dari pembelajaran fisika tersebut akan tercapai jika dalam proses pembelajarannya berjalan dengan baik.

Pada kenyataanya, yang terjadi di lapangan masih belum sesuai dengan fungsi dan tujuan yang diharapkan. Kebanyakan siswa masih mengalami kesulitan dalam memahami materi dalam pelajaran fisika terutama pada materi optik. Salah satu faktor yang menyebabkan kesulitan belajar fisika yang dialami siswa yaitu adanya miskonsepsi. Fowler dalam Suparno (2013: 5) memandang miskonsepsi sebagai suatu pengertian yang tidak akurat terhadap konsep, penggunaan konsep yang salah, klasifikasi contoh-contoh yang salah, kekacauan konsep-konsep yang berbeda, dan hubungan konsep-konsep yang tidak benar. Hal ini dikemukakan juga oleh Adiansyah, dkk (2015) yang menyatakan bahwa adakalanya apa yang dipahami siswa mengenai suatu konsep ilmiah sering kali berbeda dengan konsep yang dianut oleh para ahli. Ketidaksesuaian pemahaman konsep tersebut seringkali disebut sebagai miskonsepsi atau konsep alternatif. Jika pembelajaran fisika siswa masih mengalami miskonsepsi maka akan berdampak pada hasil belajar siswa dan pembelajaran fisika di jenjang yang lebih tinggi.

Hasil penelitian sebelumnya oleh Capriani (2016) ditemukan siswa yang masih mengalami miskonsepsi dalam materi cermin. Jumlah persentase miskonsepsi yang dialami siswa laki-laki sebesar $20 \%$ dan pada siswa perempuan sebesar $12,5 \%$. Berdasarkan penelitian tersebut maka diperlukan adanya kegiatan untuk memperbaiki miskonsepsi siswa pada materi cermin. Salah satu cara mengatasi miskonsepsi siswa yaitu dengan melakukan remediasi. Sutrisno, dkk (2007:9) mengatakan bahwa 
remediasi adalah kegiatan yang dilaksanakan untuk membetulkan kekeliruan yang dilakukan siswa. Remediasi merupakan kegiatan perbaikan yang diarahkan untuk mengatasi kesulitan belajar siswa dengan cara mengubah, memperbaiki atau memperjelas kerangka berpikir siswa (Wahyudi, 2012). Program pengajaran remedial merupakan pengajaran yang bersifat spesifik untuk menyembuhkan dan memperbaiki masalah belajar yang dialami siswa (Sri, 2013). Definisi remediasi tersebut juga sesuai dengan yang dikemukan oleh Rachman (1993:185) yaitu sebagai bentuk pengajaran yang diberikan kepada siswa untuk membantu memecahkan kesulitan belajar yang dihadapinya.

Dari berbagai definisi di atas dapat disimpulkan bahwa remediasi adalah suatu kegiatan perbaikan dengan bentuk pengajaran ulang kepada siswa untuk memecahkan persoalan kesulitan belajar siswa. Ada berbagai macam bentuk kegiatan remediasi yang dapat dilakukan untuk membantu siswa yang mengalami kesulitan belajar diantaranya sebagai berikut: 1) melaksanakan pembelajaran ulang; 2) melakukan aktifitas fisik seperti demonstrasi atau praktek; 3) kegiatan kelompok; (4) tutorial dan; 5) menggunakan sumber belajar lain (Sutrisno, dkk, 2007:21). Pada penelitian ini remediasi dilakukan dalam bentuk pengajaran ulang. Remediasi dalam bentuk pengajaran ulang dipilih karena memiliki effect size sebesar 0,48 dengan kategori sedang (Nurhayati, 2012). Menurut Wahyudi (2012), remediasi berbentuk pengajaran ulang bisa menggunakan berbagai pendekatan, metode, dan model pembelajaran untuk mengatasi kesulitan belajar siswa. Remediasi dengan pengajaran ulang dipilih agar siswa dapat memahami konsep dengan benar, membatasi miskonsespsi siswa sejak dini sehingga dapat menjadi landasan awal untuk melanjutkan konsep tersebut ke jenjang pendidikan yang selanjutnya serta memudahkan penerapan konsep dalam kehidupan sehari-hari (Sutrisno, dkk, 2007:20).

Penelitian ini melakukan meremediasi miskonsepsi siswa pada materi cermin dengan cara melakukan pengajaran ulang menggunakan media animasi di kelas VIII MTs Al Anwar Pontianak yang diharapkan mampu menurunkan jumlah miskonsepsi 
siswa dalam materi cermin. Remediasi miskonsepsi dilakukan dengan cara pengajaran ulang menggunakan media animasi di kelas VIII MTs Al Anwar Pontianak yang diharapkan mampu menurunkan jumlah miskonsepsi siswa dalam materi cermin. Tujuan dalam penelitian ini adalah untuk mengetahui hasil remediasi miskonsepsi siswa dalam materi cermin menggunakan media animasi di kelas VIII MTs Al Anwar Pontianak.

\section{METODE}

Metode yang digunakan dalam penelitian ini adalah penelitian eksperimen dengan bentuk penelitian pre-ekperimental design dan menggunakan rancangan penelitian One Group Pre-test-Posttest. Populasi dalam penelitian ini adalah siswa kelas VIII MTs Al Anwar Pontianak yang berjumlah 53 siswa terdiri dari 2 kelas. Pengambilan sampel dalam penelitian ini menggunakan sampling purposive sehingga

diperoleh sampel awal yang digunakan dalam penelitian ini yaitu siswa kelas VIII MTs Al Anwar Pontianak, setelah itu sampel awal diberikan pretest untuk mengetahui siswa yang mengalami miskonsepsi dan siswa yang miskonsepsi diberikan perlakuan berupa remediasi. Dalam penelitian ini teknik pengumpulan data yang digunakan adalah teknik pengukuran dengan tes diagnostik tiga tingkat, yaitu berupa pilihan ganda menggunakan tiga alternatif jawaban dan dengan alasan terbuka disertai tingkat keyakinan jawaban siswa. Instrumen yang digunakan pada penelitian ini diadopsi dan dimodifikasi dari Capriani (2016). Hal ini dikarenakan ditemukannya beberapa kesalahan redaksi instrumen sebelumnya sehingga perlu diadakannya validasi isi ulang. Validasi isi dilakukan dengan mengkonsultasikan instrumen kepada para ahli yang terdiri dari dua orang dosen dan satu orang guru IPA di Mts Al Anwar. Untuk mengetahui miskonsepsi siswa dalam materi cermin sebelum dan setelah diberikan remediasi dengan menggunakan media animasi di kelas VIII MTs Al Anwar Pontianak yaitu dengan cara mengelompokkan jawaban siswa pada pretest dan posttest. Untuk mengetahui apakah terjadi penurunan yang signifikan pada jumlah miskonsepsi siswa dalam materi cermin setelah diberikan remediasi dengan 
menggunakan media animasi di kelas VIII MTs Al Anwar Pontianak yaitu menggunakan Uji Mc Nemar Test. Untuk mengetahui seberapa besar efektifitas remediasi miskonsepsi siswa dalam materi cermin menggunakan media animasi di kelas VIII MTs Al Anwar Pontianak yaitu menggunakan pedoman ruas jari.

\section{HASIL DAN PEMBAHASAN}

Penelitian yang dilakukan bertujuan untuk mengetahui miskonsepsi siswa dalam materi cermin sebelum dan setelah diberikan remediasi, mengetahui penurunan yang signifikan pada jumlah miskonsepsi siswa dalam materi cermin setelah diberikan remediasi serta mengetahui seberapa besar efektifitas remediasi miskonsepsi siswa dalam materi cermin menggunakan media animasi di kelas VIII MTs Al Anwar Pontianak Tahun Ajaran 2016/2017. Perlakuan yang diberikan berupa pengajaran ulang menggunakan media animasi.

Berdasarkan Tabel 1 dan Tabel 2 terlihat bahwa sebelum dan setelah diberikan remediasi jumlah miskonsepsi tiap siswa dan jumlah miskonsepsi siswa tiap konsep berbeda-beda. Bentuk konsepsi awal siswa kadang-kadang tidak jelas dan seringkali mengandung miskonsepsi. Hal ini sejalan dengan pendapat Suparno (2013:34) yang menyatakan bahwa konsep awal ini seringkali mengandung miskonsepsi. Untuk dapat menangani miskonsepsi yang dimiliki siswa diperlukan cara-cara mengidentifikasi atau mendeteksi miskonsepsi, salah satu caranya yaitu dengan memberikan tes diagnostik berbentuk pilihan ganda disertai dengan alasan serta tingkat keyakinan. Hal ini sejalan dengan pendapat Suparno (2013:123) yang menyatakan bahwa alat deteksi miskonsepsi siswa yang sering digunakan para peneliti dan guru salah satunya yaitu dengan memberikan tes multipite choice dengan reasoning terbuka.

Pada hasil analisis data pretest ditemukan bahwa seluruh siswa kelas VIII A mengalami miskonsepsi. Dari hasil pretest hanya ditemukan jawaban siswa yang dikelompokkan dalam miskonsepsi yaitu dengan memilih jawaban salah, alasan yang 
salah dengan keyakinan tinggi dan memilih jawaban benar, alasan salah dengan keyakinan tinggi. Kebanyakan siswa miskonsepsi dengan memilih jawaban salah, alasan salah dengan keyakinan tinggi. Hal ini diduga karena konsep awal yang dimiliki siswa mengandung miskonsepsi, selain itu juga diduga dari penalaran siswa yang tidak lengkap. Hal ini sejalan dengan yang dikemukakan oleh Suparno (2013:34) yaitu miskonsepsi siswa dapat dikelompookan dalam beberapa hal, seperti prakonsepsi atau konsep awal siswa dan reasoning yang tidak lengkap/salah.

Tabel 1. Miskonsepsi Tiap Siswa pada Pretest dan Posttest

\begin{tabular}{|c|c|c|c|c|c|c|}
\hline \multirow{2}{*}{ No } & \multirow{2}{*}{$\begin{array}{l}\text { Kode } \\
\text { Siswa }\end{array}$} & \multicolumn{2}{|c|}{$\begin{array}{c}\text { Jumlah } \\
\text { Miskonsepsi }\end{array}$} & \multicolumn{2}{|c|}{$\begin{array}{l}\text { Penurunan Jumah } \\
\text { Miskonsepsi }\end{array}$} & \multirow{2}{*}{ Kategori } \\
\hline & & $\begin{array}{c}\text { Pretest } \\
\left(n_{0}\right)\end{array}$ & $\begin{array}{c}\text { Posttest } \\
\left(n_{t}\right)\end{array}$ & $(\Delta n)$ & $(\Delta n \%)$ & \\
\hline 1 & MI & 3 & 2 & 0,33 & 33 & Sedang \\
\hline 2 & IH & 3 & 1 & 0,67 & 67 & Sedang \\
\hline 3 & FR & 6 & 2 & 0,67 & 67 & Sedang \\
\hline 4 & IK & 2 & 1 & 0,50 & 50 & Sedang \\
\hline 5 & FY & 7 & 2 & 0,71 & 71 & Tinggi \\
\hline 6 & MA & 2 & 0 & 1,00 & 100 & Tinggi \\
\hline 7 & RM & 4 & 1 & 0,75 & 75 & Tinggi \\
\hline 8 & SM & 3 & 0 & 1,00 & 100 & Tinggi \\
\hline 9 & DL & 2 & 0 & 1,00 & 100 & Tinggi \\
\hline 10 & $\mathrm{DH}$ & 1 & 1 & 0,00 & 0 & Rendah \\
\hline 11 & $\mathrm{NH}$ & 1 & 1 & 0,00 & 0 & Rendah \\
\hline 12 & NL & 3 & 3 & 0,00 & 0 & Rendah \\
\hline 13 & $\mathrm{RD}$ & 4 & 3 & 0,25 & 25 & Rendah \\
\hline 14 & YA & 2 & 0 & 1,00 & 100 & Tinggi \\
\hline 15 & $\mathrm{RP}$ & 3 & 1 & 0,67 & 67 & Sedang \\
\hline 16 & AA & 5 & 1 & 0,80 & 80 & Tinggi \\
\hline 17 & SF & 4 & 1 & 0,75 & 75 & Tinggi \\
\hline
\end{tabular}

Profil miskonsepsi tertinggi sebelum diremediasi terdapat pada konsep sifat bayangan pada cermin datar dengan jumlah siswa yang mengalami miskonsepsi sebanyak 11 orang siswa yaitu IH, FR, IK, MA, RM, SM, DL, RD, RP, AA, SF. Secara intuisi siswa beranggapan bahwa sifat bayangan pada cermin datar bersifat nyata, padahal sifat bayangan pada cermin datar bersifat maya karena bayangan bisa 
dilihat oleh mata tetapi tidak dapat ditangkap oleh layar. Diduga siswa beranggapan bayangan bersifat nyata dikarenakan bayangan dapat dilihat dengan jelas pada cermin datar. Selain itu terdapat siswa yang memilih jawaban benar namun disertai alasan yang salah, dengan menuliskan alasan yang tidak lengkap dan menyimpang. Sehingga dalam identifikasinya siswa banyak yang mengalami miskonsepsi.

Tabel 2. Miskonsepsi Siswa Tiap Konsep pada Pretest dan Posttest

\begin{tabular}{|c|c|c|c|c|c|c|}
\hline \multirow[t]{2}{*}{ No } & \multirow[t]{2}{*}{ Konsep } & \multicolumn{2}{|c|}{$\begin{array}{c}\text { Jumlah } \\
\text { Miskonsepsi }\end{array}$} & \multicolumn{2}{|c|}{$\begin{array}{l}\text { Penurunan } \\
\text { Jumah } \\
\text { Miskonsepsi } \\
\end{array}$} & \multirow[t]{2}{*}{ Kategori } \\
\hline & & $\begin{array}{c}\text { Pretest } \\
\left(s_{0}\right)\end{array}$ & $\begin{array}{c}\text { Posttest } \\
\left(s_{t}\right)\end{array}$ & $(\Delta s)$ & $(\Delta s \%)$ & \\
\hline 1 & Hukum snellius & 8 & 2 & 0,75 & 75 & Tinggi \\
\hline 2 & $\begin{array}{l}\text { Jalannya sinar pada } \\
\text { cermin datar }\end{array}$ & 3 & 2 & 0,33 & 33 & Sedang \\
\hline 3 & $\begin{array}{l}\text { Pembentukan } \\
\text { bayangan pada } \\
\text { cermin datar }\end{array}$ & 8 & 3 & 0,625 & 62,5 & Sedang \\
\hline 4 & $\begin{array}{l}\text { Sifat bayangan } \\
\text { pada cermin datar }\end{array}$ & 11 & 1 & 0,91 & 91 & Tinggi \\
\hline 5 & $\begin{array}{l}\text { Sifat bayangan } \\
\text { pada cermin } \\
\text { cekung }\end{array}$ & 7 & 2 & 0,71 & 67 & Tinggi \\
\hline 6 & $\begin{array}{l}\text { Sifat bayangan } \\
\text { pada cermin } \\
\text { cembung }\end{array}$ & 5 & 2 & 0,60 & 60 & Sedang \\
\hline 7 & $\begin{array}{l}\text { Letak ruang benda } \\
\text { dan ruang } \\
\text { bayangan }\end{array}$ & 3 & 1 & 0,67 & 67 & Sedang \\
\hline 8 & $\begin{array}{l}\text { Penggunaan cermin } \\
\text { dalam kehidupan } \\
\text { sehari-hari }\end{array}$ & 10 & 7 & 0,30 & 30 & Rendah \\
\hline & Rata-rata & 6,87 & 2,5 & 0,61 & 61,23 & Sedang \\
\hline
\end{tabular}

Pada saat posttest terdapat 1 orang siswa $(5,88 \%)$ yang mengalami miskonsepsi dalam konsep sifat bayangan pada cermin datar dengan memilih jawaban salah, alasan salah dengan keyakinan tinggi. Siswa yang mengalami miskonsepsi pada 
posttest tersebut juga mengalami miskonsepsi yang sama pada pretest. Pada hasil analisis data posttest ditemukan bahwa masih terdapat siswa kelas VIII A yang mengalami miskonsepsi, hanya 4 orang siswa saja yang sudah tidak mengalami miskonsepsi yaitu RM, SM, DL, YA. Hal ini sejalan dengan yang diungkapkan Berg (1991:5) bahwa miskonsepsi awet dan sulit diubah. Dalam menjawab soal pada posttest kebanyakan siswa sudah memilih jawaban benar namun masih memberikan alasan yang salah dengan keyakinan tinggi. Kemungkinan siswa tersebut sudah memahami konsep namun masih kesulitan dalam mendeskripsikan konsep yang mereka pahami tersebut sehingga alasan yang mereka cantumkan kurang lengkap bahkan keliru sehingga dalam identifikasinya siswa dikelompokkan dalam miskonsepsi. Hal ini sejalan dengan yang diungkapkan Suparno (2013:38) bahwa alasan yang tidak lengkap dapat disebabkan karena informasi yang diperoleh atau data yang didapatkan tidak lengkap dan juga reasoning yang salah dapat juga terjadi karena logika yang salah dalam mengambil kesimpulan sehingga terjadi miskonsepsi.

Namun setelah diremediasi terjadi reduksi kuantitas miskonsepsi siswa. Profil miskonsepsinya masih variatif untuk setiap konsep. Profil miskonsepsi tertinggi setelah diremediasi terdapat pada konsep penggunaan cermin dalam kehidupan sehari-hari. Kebanyakan siswa sudah memilih jawaban benar, namun memberikan alasan yang kurang lengkap bahkan menyimpang. Siswa sebenarnya paham terhadap suatu konsep namun diduga siswa masih kesulitan dalam mendeskripsikan konsepkonsep yang mereka ketahui secara tertulis. Namun terdapat satu orang siswa yang memilih jawaban salah, alasan benar dengan keyakinan tinggi, hal ini diduga siswa masih belum dapat membedakan cermin cekung dan cermin cembung sehingga dalam identifikasinya siswa dikelompokkan ke dalam miskonsepsi.

Untuk mengetahui penurunan jumlah miskonsepsi siswa yaitu denngan menghitung harga proporsi penurunan jumlah miskonsepsi tiap siswa dan tiap konsep. Berdasarkan Tabel 1. diperoleh rata-rata penurunan miskonsepsi tiap siswa sebesar 59,57\%, sedangkan berdasarkan Tabel 2 diperoleh rata-rata penurunan miskonsepsi siswa tiap konsep sebesar $61,23 \%$. Hal ini disebabkan oleh pemahaman 
siswa yang berubah setelah menerima pembelajaran dengan menggunakan media animasi. Siswa dapat mengetahui konsepsi yang sesuai dengan konsepsi ilmuwan dengan melihat animasi yang ditampilkan sehingga dapat memudahkan siswa untuk mengetahui letak kesalahan yang dilakukan saat pretest dan mengubah gagasan siswa yang tidak benar. Hal ini didukung oleh Ika (2014) yang menyatakan bahwa media animasi dapat membuat materi pelajaran yang abstrak menajdi konkret. Oleh karena itu pembelajaran menggunakan media animasi dapat memudahkan siswa dalam memahami materi pelajaran yang bersifat abstrak seperti dalam materi cermin ini. Dari hasil tersebut dapat disimpulkan bahwa remediasi menggunakan media animasi dapat menurunkan jumlah miskonsepsi siswa. Hasil ini sesuai dengan penelitian sebelumnya Selina (2016) yang mengatakan bahwa terjadi penurunan pada jumlah miskonsepsi siwa setelah dilakukan remediasi menggunakan simulasi flash.

Sedangkan untuk mengetahui penurunan jumlah miskonsepsi siswa yang signifikan baik pada tiap siswa maupun tiap konsep digunakan uji Mc Nemar Test. Hasil uji Mc Nemar Test secara keseluruhan dapat dilihat pada Tabel 3 sedangkan pada tiap siswa ditujukkan pada Tabel 4, dan pada tiap konsep ditunjukkan pada Tabel 5 yang menunjukkan adanya perubahan jumlah miskonsepsi antara sebelum dan setelah diremediasi. Pada Tabel 4 dapat dilihat bahwa hanya 9 orang siswa saja yang mengalami penurunan yang signifikan, sedangkan pada Tabel 5 terlihat bahwa hanya 5 konsep yang mengalami penurunan yang signifikan. Namun secara keseluruhan terdapat penurunan yang signifikan pada jumlah miskonsepsi siswa dalam materi cermin setelah diberikan remediasi menggunakan media animasi di kelas VIII MTs Al Anwar Pontianak yang ditandai dengn Ha diterima pada perhitungan pengujian hipotesis secara umum yang disajikan pada Tabel 3. Hasil ini sesuai dengan beberapa hasil penelitian sebelumnya Anon (2016) dan Lioni (2016) mengatakan bahwa remediasi miskonsepsi berbantuan animasi berpengaruh signifikan terhadap penurunan jumlah miskonsepsi siswa. 
Tabel 3. Hasil Pengujian Hipotesis Menggunakan Uji Mc Nemar Test

\begin{tabular}{cccc}
\hline $\boldsymbol{x}^{2}$ hitung & $\boldsymbol{x}^{2}$ tabel & Pengujian & Kesimpulan \\
\hline 24,453 & 3,841 & $x^{2}$ hitung $>x^{2}$ Tabel & Ha diterima \\
\hline
\end{tabular}

Tabel 4. Hasil Pengujian Signifikansi Jumlah Penurunan Miskonsepsi Setelah Remediasi untuk Tiap Siswa

\begin{tabular}{|c|c|c|c|c|c|}
\hline No & $\begin{array}{l}\text { Kode } \\
\text { Siswa }\end{array}$ & $\begin{array}{c}x^{2} \\
\text { hitung }\end{array}$ & $\begin{array}{c}X^{2} \\
\text { tabel }\end{array}$ & Pengujian & Kesimpulan \\
\hline 1 & MI & 1,33 & 3,841 & $\begin{array}{c}x^{2} \text { hitung }<x^{2} \\
\text { Tabel }\end{array}$ & $\begin{array}{c}\text { Tidak terjadi } \\
\text { penurunan yang } \\
\text { signifikan }\end{array}$ \\
\hline 2 & $\mathrm{IH}$ & 3,20 & 3,841 & $\begin{array}{c}x^{2} \text { hitung }>x^{2} \\
\text { Tabel }\end{array}$ & $\begin{array}{c}\text { Tidak terjadi } \\
\text { penurunan yang } \\
\text { signifikan }\end{array}$ \\
\hline 3 & FR & 6,25 & 3,841 & $\begin{array}{c}x^{2} \text { hitung }>x^{2} \\
\text { Tabel }\end{array}$ & $\begin{array}{l}\text { Terjadi penurunan } \\
\text { yang signifikan }\end{array}$ \\
\hline 4 & IK & 1,33 & 3,841 & $\begin{array}{c}x^{2} \text { hitung }<x^{2} \\
\text { Tabel }\end{array}$ & $\begin{array}{l}\text { Tidak terjadi } \\
\text { penurunan yang } \\
\text { signifikan }\end{array}$ \\
\hline 5 & FY & 6 & 3,841 & $\begin{array}{c}x^{2} \text { hitung }>x^{2} \\
\text { Tabel }\end{array}$ & $\begin{array}{l}\text { Terjadi penurunan } \\
\text { yang signifikan }\end{array}$ \\
\hline 6 & MA & 4,5 & 3,841 & $\begin{array}{c}x^{2} \text { hitung }>x^{2} \\
\text { Tabel }\end{array}$ & $\begin{array}{l}\text { Terjadi penurunan } \\
\text { yang signifikan }\end{array}$ \\
\hline 7 & $\mathrm{RM}$ & 5,33 & 3,841 & $\begin{array}{c}x^{2} \text { hitung }>x^{2} \\
\text { Tabel }\end{array}$ & $\begin{array}{l}\text { Terjadi penurunan } \\
\text { yang signifikan }\end{array}$ \\
\hline 8 & SM & 5,33 & 3,841 & $\begin{array}{c}x^{2} \text { hitung }>x^{2} \\
\text { Tabel }\end{array}$ & $\begin{array}{c}\text { Terjadi penurunan } \\
\text { yang signifikan }\end{array}$ \\
\hline 9 & DL & 4,5 & 3,841 & $\begin{array}{c}x^{2} \text { hitung }>x^{2} \\
\text { Tabel }\end{array}$ & $\begin{array}{c}\text { Terjadi penurunan } \\
\text { yang signifikan }\end{array}$ \\
\hline 10 & DH & 0,5 & 3,841 & $\begin{array}{c}x^{2} \text { hitung }<x^{2} \\
\text { Tabel }\end{array}$ & $\begin{array}{l}\text { Tidak terjadi } \\
\text { penurunan yang } \\
\text { signifikan }\end{array}$ \\
\hline 11 & $\mathrm{NH}$ & 0,5 & 3,841 & $\begin{array}{c}x^{2} \text { hitung }<x^{2} \\
\text { Tabel }\end{array}$ & $\begin{array}{l}\text { Tidak terjadi } \\
\text { penurunan yang } \\
\text { signifikan }\end{array}$ \\
\hline 12 & NL & 0,25 & 3,841 & $\begin{array}{c}x^{2} \text { hitung }<x^{2} \\
\text { Tabel }\end{array}$ & $\begin{array}{l}\text { Tidak terjadi } \\
\text { penurunan yang } \\
\text { signifikan }\end{array}$ \\
\hline 13 & RD & 1,33 & 3,841 & $\begin{array}{c}x^{2} \text { hitung }<x^{2} \\
\text { Tabel }\end{array}$ & $\begin{array}{c}\text { Tidak terjadi } \\
\text { penurunan yang }\end{array}$ \\
\hline
\end{tabular}




\begin{tabular}{|c|c|c|c|c|c|}
\hline 14 & YA & 4,5 & 3,841 & $\begin{array}{c}x^{2} \text { hitung }>x^{2} \\
\text { Tabel }\end{array}$ & $\begin{array}{l}\text { signifikan } \\
\text { Terjadi penurunan } \\
\text { vang signifikan }\end{array}$ \\
\hline 15 & $\mathrm{RP}$ & 2,25 & 3,841 & $\begin{array}{c}x^{2} \text { hitung }<x^{2} \\
\text { Tabel }\end{array}$ & $\begin{array}{l}\text { yang signilikan } \\
\text { Tidak terjadi } \\
\text { penurunan yang } \\
\text { signifikan }\end{array}$ \\
\hline 16 & AA & 6,25 & 3,841 & $\begin{array}{c}x^{2} \text { hitung }>x^{2} \\
\text { Tabel }\end{array}$ & $\begin{array}{l}\text { Terjadi penurunan } \\
\text { yang signifikan }\end{array}$ \\
\hline 17 & SF & 5,33 & 3,841 & $\begin{array}{c}x^{2} \text { hitung }>x^{2} \\
\text { Tabel }\end{array}$ & $\begin{array}{l}\text { Terjadi penurunan } \\
\text { yang signifikan }\end{array}$ \\
\hline
\end{tabular}

Tabel 5. Hasil Pengujian Signifikansi Jumlah Penurunan Miskonsepsi Setelah Remediasi untuk Tiap Konsep

\begin{tabular}{|c|c|c|c|c|c|}
\hline No & Konsep & $\begin{array}{c}X^{2} \\
\text { hitung }\end{array}$ & $\begin{array}{c}X^{2} \\
\text { tabel }\end{array}$ & Pengujian & Kesimpulan \\
\hline 1 & $\begin{array}{l}\text { Hukum } \\
\text { Snellius }\end{array}$ & 6,125 & 3,841 & $\begin{array}{c}x^{2} \text { hitung }> \\
x^{2} \text { Tabel }\end{array}$ & $\begin{array}{c}\text { Terjadi } \\
\text { penurunan } \\
\text { yang } \\
\text { signifikan }\end{array}$ \\
\hline 2 & $\begin{array}{l}\text { Jalannya sinar } \\
\text { pada cermin } \\
\text { datar }\end{array}$ & 0,80 & 3,841 & $\begin{array}{c}x^{2} \text { hitung }< \\
x^{2} \text { Tabel }\end{array}$ & $\begin{array}{l}\text { Tidak terjadi } \\
\text { penurunan } \\
\text { yang } \\
\text { signifikan } \\
\end{array}$ \\
\hline 3 & $\begin{array}{l}\text { Pembentukan } \\
\text { bayangan pada } \\
\text { cermin datar }\end{array}$ & 4,00 & 3,841 & $\begin{array}{c}x^{2} \text { hitung }> \\
x^{2} \text { Tabel }\end{array}$ & $\begin{array}{c}\text { Terjadi } \\
\text { penurunan } \\
\text { yang } \\
\text { signifikan } \\
\end{array}$ \\
\hline 4 & $\begin{array}{l}\text { Sifat bayangan } \\
\text { pada cermin } \\
\text { datar }\end{array}$ & 12,10 & 3,841 & $\begin{array}{c}x^{2} \text { hitung }> \\
x^{2} \text { Tabel }\end{array}$ & $\begin{array}{c}\text { Terjadi } \\
\text { penurunan } \\
\text { yang } \\
\text { signifikan }\end{array}$ \\
\hline 5 & $\begin{array}{l}\text { Sifat bayangan } \\
\text { pada cermin } \\
\text { cekung }\end{array}$ & 3,841 & 3,841 & $\begin{array}{c}x^{2} \text { hitung }> \\
x^{2} \text { Tabel }\end{array}$ & $\begin{array}{c}\text { Terjadi } \\
\text { penurunan } \\
\text { yang } \\
\text { signifikan } \\
\end{array}$ \\
\hline 6 & $\begin{array}{l}\text { Sifat bayangan } \\
\text { pada cermin } \\
\text { cembung }\end{array}$ & 3,125 & 3,841 & $\begin{array}{c}x^{2} \text { hitung }< \\
x^{2} \text { Tabel }\end{array}$ & $\begin{array}{c}\text { Tidak terjadi } \\
\text { penurunan } \\
\text { yang } \\
\text { signifikan } \\
\end{array}$ \\
\hline
\end{tabular}




\begin{tabular}{clcccc}
\hline 7 & $\begin{array}{l}\text { Letak ruang } \\
\text { benda dan } \\
\text { ruang } \\
\text { bayangan }\end{array}$ & 4,50 & 3,841 & $x^{2}$ hitung $>$ & $\begin{array}{c}\text { Terjadi } \\
x^{2} \text { Tabel } \\
\text { penurunan } \\
\text { yang } \\
\text { signifikan }\end{array}$ \\
\hline 8 & $\begin{array}{l}\text { Penggunaan } \\
\text { cermin dalam } \\
\text { kehidupan } \\
\text { sehari-hari }\end{array}$ & 3,20 & 3,841 & $x^{2}$ hitung $>$ & $\begin{array}{c}\text { Tidak terjadi } \\
\text { penurunan } \\
\text { yang } \\
\text { signifikan }\end{array}$ \\
\hline
\end{tabular}

Setelah dilakukan remediasi, ditemukan beberapa hal dalam peneltian ini mengenai perubahan pemahaman pada siswa. Pemahaman siswa yang awalnya miskonsepsi berubah menjadi siswa paham konsep dan siswa tidak paham konsep. Perubahan tersebut belum dapat dikatakan kearah positif karena tidak semua siswa menjadi paham konsep melainkan siswa masih memiliki keraguan bahkan tidak yakin dalam pilihan jawabannya sehingga dalam identifikasinya siswa menjadi tidak paham konsep.

Selain itu ditemukan juga perubahan pemahaman siswa lainnya antara lain: siswa yang tidak miskonsepsi dengan kategori tidak paham konsep menjadi miskonsepsi. Siswa yang tidak mengalami perubahan dari sebelum dan setelah remediasi, yaitu siswa tetap mengalami miskonsepsi. Siswa yang sudah tidak mengalami miskonsepsi namun memiliki nilai-nilai yang rendah pada pengerjaan LKS. Siswa yang perubahannya menjadi tidak paham konsep diduga siswa menjadi bingung dan tidak yakin dengan pengetahuan yang sudah mereka pahami dan pengetahuan yang baru mereka pelajari.

Dari penjabaran tersebut, temuan-temuan yang diperoleh dapat terjadi karena beberapa kemungkinan yaitu: pertama diduga siswa sudah lupa dengan pembelajaran yang telah dilakukan, kedua diduga karena lamanya jeda waktu pemeberian posttest setelah dilakukan remediasi, ketiga diduga siswa tidak memperhatikan pembelajaran pada saat remediasi yang dilihat dari hasil LKS, keempat diduga siswa salah mengkonstruksi pengetahuan yang diperolehnya, kelima diduga siswa lebih 
mengingat konsep awal yang mereka miliki dibandingkan konsep baru yang mereka pelajari, keenam diduga tahap perkembangan kognitif siswa yang berbeda-beda dan ketujuh diduga karena kemampuan siswa yang berbeda-beda.

Hal ini sesuai dengan yang diungkapan Suparno (2013:34) yang mengatakan bahwa miskonsepsi pada siswa dapat dikelompokkan dalam beberapa hal, antara lain: prakonsepsi atau konsep awal, reasoning yang tidak lengkap atau salah, intuisi yang salah, tahap perkembangan kognitif siswa, dan kemampuan siswa. Selain itu juga sejalan dengan fakta mengenai miskonsepsi yang diungkapkan oleh Berg (1991:17) yang mengatakan bahwa miskonsepsi sulit sekali diperbaiki, seringkali sisa miskonsepsi terus menerus menggangu, seringkali terjadi regresi, yaitu mahasiswa yang sudah pernah mengatasi miskonsepsi, beberapa waktu kemudian salah lagi, dan siswa yang pandai dan yang lemah dua-duanya memiliki miskonsepsi.

Ada beberapa upaya yang dapat dilakukan untuk memperbaiki miskonsepsi, satu diantaranya adalah dengan mencari perlakuan yang sesuai untuk mengatasi permasalaha tersebut (Suparno, 2013:85). Perlakuan yang dilakukan dalam penelitian ini adalah dengan memberikan pengajaran ulang dengan menggunakan media animasi. Penggunaan media animasi dalam pembelajaran dapat membuat materi pelajaran yang abstrak menjadi lebih konkrit serta dapat membantu mengatasi keterbatasan indera manusia (Ika, 2014). Secara keseluruhan remediasi dengan pengajaran ulang menggunakan media animasi dalam materi cermin dikatakan cukup efektif untuk menurunkan miskonsepsi pada tiap siswa dan miskonsepsi siswa tiap konsep dengan tingkat efektifitas sedang yang ditunjukkan pada Tabel 1 dan Tabel 2.

Walaupun sudah diremediasi ternyata masih terdapat siswa yang mengalami miskonsepsi, dari 17 orang siswa yang diremediasi hanya 4 orang siswa saja yang tidak mengalami miskonsepsi. Hal tersebut menandakan bahwa miskonsepsi sifatnya tetap dan sulit untuk diperbaiki seperti yang diungkapkan oleh Suparno (2013:7) bahwa miskonsepsi sulit dibenahi atau dibertulkan. Temuan ini sejalan dengan pendapat Berg (1991:17) yang menyatakan bahwa penelitian mengenai beberpa cara 
untuk mengatasi miskonsepsi belum menghasilkan cara yang baik untuk menghapusnya. Namun berbagai cara remediasi dapat mengurangi miskonsepsi siswa seperti yang ditemukan peneliti dalam penelitian ini.

\section{SIMPULAN}

Berdasarkan hasil pembahasan dan temuan dalam penelitian ini maka dapat disimpulkan bahwa hasil remediasi pada siswa kelas VIII MTs Al Anwar Pontianak dalam materi cermin menggunakan media animasi efektif dalam menurunkan jumlah miskonsepsi pada siswa. Siswa yang mengalami miskonsepsi dalam materi cermin sebelum dilakukan remediasi dengan menggunakan media animasi siswa yang berjumlah 17 orang. Sedangkan siswa yang mengalami miskonsepsi dalam materi cermin setelah dilakukan remediasi dengan menggunakan media animasi yaitu mengalami penurunan menjadi 13 orang siswa, namun masih ditemukan miskonsepsi pada tiap konsep dalam materi cermin. Terjadi penurunan yang signifikan pada jumlah miskonsepsi siswa dalam materi cermin setelah diberikan remediasi dengan menggunakan media animasi di kelas VIII MTs Al Anwar Pontianak. Besar efektifitas remediasi miskonsepsi siswa dalam materi cermin menggunakan media animasi di kelas VIII MTs Al Anwar Pontianak yaitu sebesar 59,57 dengan kategori sedang untuk efektifitas miskonsepsi tiap siswa dan 61,23 unruk efektifitas miskonsepsi siswa tiap konsep dengan kategori sedang.

\section{DAFTAR PUSTAKA}

Adiansyah, D. S \& Setyarsih, W. (2015). Identifikasi Miskonsepsi dan Penyebab Miskonsepsi Siswa dengan Three-tier Diagnostic Test pada Materi Dinamika Rotasi. Jurnal Inovasi Pendidikan Fisika (JIPF), 04 (03), 6770.

Anon., Djudin. T., \& Mursyid, S. B. (2016). Remediasi Miskonsepsi pada Perpindahan Kalor Menggunakan Model Direct Instruction Berbantuan 
Media Animasi di MAN 2 Filial Pontianak. Jurnal Pendidikan dan Pembelajaran, 5 (12), 1-14.

Berg, V., D. (1991). Miskonsepsi Fisika dan Remediasi. Salatiga: Universitas Kristen Satya Wacana.

Capriani, I. (2016). Analisis Konsepsi Siswa pada Konsep Cermin Ditinjau dari Gender Kelas VIII Mts Al Anwar Pontianak. Skripsi IKIP PGRI Pontianak: tidak diterbitkan.

Depdiknas. (2006). Kurikulum Tingkat Satuan Pendidikan (KTSP). Jakarta: Departemen Pendidikan Nasional.

Ika, C. (2014). Makalah Media Audio Visual dan Animasi. (Online, tersedia di ikacahya94.blogspot.co.id/2014/01/makalah-media-audio-visual-dananimasi, diakses Tanggal 17 April 2017)

Lioni., Sutrisno, L., \& Hamdani. (2014). Remediasi Miskonsepsi Siswa Tentang Kecepatan Menggunakan Keterampilan Bertanya Berbantuan Media Animasi di SMP. Jurnal Pendidikan dan Pembelajaran, 3 (7), 1-9.

Nurhayati. 2012. Penyediaan Booklet untuk Meremediasi Kesulitan Siswa dalam Memahami Konsep Gerak Parabola di Kelas XI SMA Negeri 7 Pontianak. Jurnal edukasi, Vol. 8, No.2, pp192-200.

Rusman., Kurniawan, D., Riyana, C. (2013). Pembelajaran Berbasis Teknologi Informasi dan Komunikasi. Jakarta: Rajawali Pers.

Selina, S. A., Tandililing, E., \& Mursyid, S. Remediasi Miskonsepsi Materi Pematulan Cahaya Menggunakan Simulasi Flash pada Siswa SMP. Jurnal Pendidikan dan Pembelajaran, 5 (2).

Sri, Titin Ratama. (2013). Remediasi Miskonsepsi Konsep gerak Lurus Menggunkan Pendekatan Konflik Kognitif. Skripsi pada UIN SUNAN KALIJAGA Yogyakarta. (Online, tersedia di http://digilib.uin-suka.ac.id, diakses tanggal10 Februari 2017).

Suparno, Paul. (2013). Miskonsepsi \& Perubahan Konsep dalam Pendidikan Fisika. Jakarta: PT Gramedia.

Sutrisno, L., Kresnadi, H., \& Kartono. (2007). Pengembangan Pembelajaran IPA SD. Pontianak: LPJJ PGSD. 
Wahyudi. (2012). Implementasi Program Remediasi Pada Materi Fisika Di SMP Negeri 08 Pontianak: Jurnal Edukasi, 8 (2), 172-179. 